\title{
Wastewater treatment of mining enterprises from nitrogen compounds in the Arctic
}

\author{
Anna Korotaeva ${ }^{1, *}$ \\ ${ }^{1}$ Postgraduate, Department of Geoecology, Saint-Petersburg mining university, 199106, Vasilievski ostrov, 21 linia, 2, Russia
}

\begin{abstract}
Open pit mining using explosives based on ammonium nitrate leads to wastewater pollution with nitrogen compounds. In case of insufficient wastewater treatment, pollutants enter surface-water bodies. Excessive concentration of nitrogen compounds in water leads to the development of the process of eutrophication, which adversely affects the vital activity of aquatic organisms and humans. At the moment, a common method of wastewater treatment from nitrogen compounds is a biological treatment method using devices such as aeration chambers, oxidation tanks and slim filters. An alternative option for biological treatment is the introduction of algae into wastewater. In the conditions of the Arctic, it is difficult to carry out biological treatment using algae due to low temperatures throughout the year. In this study, the feasibility of using the frost-resistant strain Chlorella kessleri VKPM A1-11ARW for the effluents treatment from nitrogen compounds was tested. Model solutions with a known nitrates concentration were used. Experiments were carried out at two specified temperatures for comparison. The results showed that by the end of the 10-day experiment, the nitrates extraction efficiency at standard temperature $\left(20{ }^{\circ} \mathrm{C}\right)$ was from $40.3 \%$ to $71.8 \%$, at low temperature $\left(3{ }^{\circ} \mathrm{C}\right.$ ) was from $30.4 \%$ to $73.6 \%$.
\end{abstract}

\section{Introduction}

The problem of pollution of water bodies with nutrients, in particular nitrogen compounds, was raised in the XX century. Scientists from Finland, USA, Norway, Canada, Germany and Russia conducted research to reduce the amount of nutrients in the discharged wastewater [1-3]. In 1973, at the International Conference in Canada, issues related to wastewater treatment in a the Arctic and the study of the effect of low temperatures on the processes of biological and physicochemical process from biogenic elements were considered. In particular, it is said that in Finland the problem of reducing the concentration of nitrogen in the discharged wastewater has become urgent after the adoption of the Law on the Protection of Water Resources, in Sweden - the Law on Environmental Protection [2].

The main danger of nitrogen intake is associated with the development of the eutrophication process in water bodies and shoreland, which negatively affects the vital activity of living organisms. This process leads to a change in the temperature and oxygen regimes of the reservoir, as well as a change in colour and organoleptic parameters [4-6]. The presence of nitrates in water bodies leads to the rapid growth of vegetation and to their further death. At the same time, being converted to the nitrite form, nitrates can negatively affect the human cardiovascular and nervous systems. Thus, we can talk about the need to solve the problem of wastewater pollution with nitrogen compounds [7].
The issue of effluents treatment from nitrogen compounds in a cold climate is an urgent issue. Thus, scientists from Norway examined two multistage systems for the treatment of domestic wastewater in the northern regions of the country. Treatment systems were constructed wetlands [8].

There are known researchs on the removal of nitrogen compounds from wastewater using microalgae systems. Scientists from Manitoba conducted a comparative analysis of systems consisting of a consortium system of microalgae and bacteria, as well as only microalgae, which were used mainly for additional treatment of incoming wastewater. Studies by scientists from other countries (China, Denmark, the Netherlands, etc.) were cited, indicating the existence of the problem of nitrogen pollution of water bodies at the present time. Basically, various strains of the green microalga Chlorella were used for treatment [4].

In the Arctic, the temperature near the sea shore ranges from $2{ }^{\circ} \mathrm{C}$ to $3{ }^{\circ} \mathrm{C}$, in the mainland up to $6-10{ }^{\circ} \mathrm{C}$ [9]. These temperature conditions impose restrictions on the use of microalgae for wastewater treatment due to the limitation of their growth. However, algae can adapt to northern climate and endure extreme cold temperatures for most of the year.

Some scientists have considered the feasibility of using strains of microalgae for wastewater treatment in the northern regions [10]. However, up to now, rare studies have been conducted to remove nitrogen compounds from wastewater of mining enterprises using

\footnotetext{
*Corresponding author: $\underline{\text { aekor@mail.ru }}$
} 
frost-resistant strains of microalgae, so research in this area is essential and significant.

In the present study, wastewater from an iron-mining enterprise located beyond the Arctic circle is used as the matter of research. Development is carried out in an open pit with drilling and blasting operations. The volume of generated wastewater in the quarry averages from 1200 to 1900 thousand $\mathrm{m}^{3} /$ year. A feature of the pollution of quarry waters is the presence of nitrogen compounds in them as a result of the use of ammonium nitrate in the production of mass explosions.

The resulting water flows into a sump, from which a pumping unit transports to a gravity collector. Through this structure, wastewater is directed to a treatment pond reaching $260 \mathrm{~m}$ in length, $100 \mathrm{~m}$ in width and $2.5 \mathrm{~m}$ in depth. The treatment pond is located on the site of the former quarry. In this hydrotechnical structure, water is settled and filtered through a filtering dam from mechanical impurities, then it is discharged into a swamp through a diversion channel.

At the entrance to the treatment pond, the concentration of nitrates in the wastewater is $143 \pm 0.15$ $\mathrm{mg} / \mathrm{L}$, at the outlet of the wastewater, the concentration is $113 \pm 0.15 \mathrm{mg} / \mathrm{L}$.

\section{Methods}

For laboratory experiments, the frost-resistant strain Chlorella kessleri VKPM A1-11 ARW was chosen, which has a high value of cultivation plasticity both in natural reservoirs and in cultivators. In addition, this strain retains its population size in winter and has the highest productivity in comparison with strains of Chlorella vulgaris.

Experiments were targeted on removing nitrates from aqueous solutions of various concentrations at different temperatures by introducing a cultured strain of the alga Chlorella kessleri VKPM A1-11 ARW into them. Experiments were carried out at $20{ }^{\circ} \mathrm{C}$ and $3{ }^{\circ} \mathrm{C}$ to compare treatment performance under favourable temperature conditions and at low temperatures.

The microalgae Chlorella kessleri VKPM A1-11 ARW was grown in the Tamiya nutrient medium, the main component of which is $\mathrm{KNO}_{3}$ with a concentration of $2.5 \mathrm{~g} / \mathrm{L}$. The increased content of nitrates makes it impossible to use the nutrient medium in its original form for the subsequent experiment. In this regard, it was decided to prepare the Chlorella kessleri VKPM A111 ARW strain in 50\% Tamiya's nutrient medium under nitrogen starvation. The actual cultivation process was carried out in the KV-05 cultivator for 18 days.

To carry out the experiment, model solutions were prepared with a given concentration of nitrates, namely $50 \mathrm{mg} / \mathrm{L}, 75 \mathrm{mg} / \mathrm{L}, 100 \mathrm{mg} / \mathrm{L}, 150 \mathrm{mg} / \mathrm{L}$, and $200 \mathrm{mg} / \mathrm{L}$. To conduct laboratory experiments on the extraction of nitrates from aqueous solutions using microalgae, two samples of $50 \mathrm{ml}$ of each model solution were prepared. $5 \mathrm{ml}$ of chlorella solution with an optical density of 1.967 was added to each sample. The determination of the optical density was carried out on an IPS-03 suspension density meter. The first five samples (one sample of each model solution) were left in the laboratory room on the table. The second five samples (one sample of each model solution) were placed in a thermostat with a temperature of $3^{\circ} \mathrm{C}$. The change in the concentration of nitrates in solutions was studied for 10 days.

Determination of the concentration of nitrates in model solutions was determined using ionometric and colourimetric methods. Ionometry was performed using an EXPERT-001 analyzer and an ion-selective electrode for nitrates. Colourimetry was carried out on the basis of a portable photocolourimeter "EKOTEST-2020" using modern techniques. Pre-model solutions for photocolourimetry were filtered through a filter. Then a preliminary reduction of the nitrates to nitrites with a zinc reducing agent was performed, followed by the formation of a nitrogen dye as a result of the reaction of the nitrites with Griss reagent. The nitrogen dye has a red-violet colour, the intensity of which is determined by the concentration of the nitrate ion in the solution.

\section{Results and discussion}

The averaged results of the two applied methods for determining the concentration of nitrates in model solutions are presented in Table 1 (for 0,7 and 10 days). The graphs of the decrease in the concentration of nitrates in the model solutions are shown in Fig. 1 and Fig. 2.

Table 1. Results of the experiments

\begin{tabular}{|c|c|c|c|c|c|}
\hline \multirow{3}{*}{$\begin{array}{c}\text { Experi- } \\
\text { ment } \\
\text { tempe- } \\
\text { rature, }{ }^{\circ} \mathrm{C}\end{array}$} & \multicolumn{4}{|c|}{$\mathrm{NO}_{3}^{-}$concentration, $\mathrm{mg} / \mathrm{L}$} & \multirow{3}{*}{$\begin{array}{c}\text { Treat- } \\
\text { ment } \\
\text { efficien } \\
\text { cy, \% }\end{array}$} \\
\hline & \multirow{2}{*}{$\begin{array}{l}\text { № model } \\
\text { solution }\end{array}$} & \multicolumn{3}{|c|}{ Time (day) } & \\
\hline & & $\mathbf{0}$ & 7 & 10 & \\
\hline \multirow{5}{*}{20} & 1 & 49.4 & 43.8 & 24.0 & 51.4 \\
\hline & 2 & 74.7 & 55.7 & 41.6 & 44.3 \\
\hline & 3 & 96.3 & 89.4 & 57.5 & 40.3 \\
\hline & 4 & 148.1 & 74.0 & 51.3 & 65.4 \\
\hline & 5 & 203.0 & 62.3 & 57.3 & 71.8 \\
\hline \multirow{4}{*}{3} & 1 & 49.4 & 44.7 & 30.4 & 38.5 \\
\hline & 2 & 74.7 & 60.7 & 52.0 & 30.4 \\
\hline & 3 & 96.3 & 89.1 & 63.3 & 34.3 \\
\hline & 4 & 148.1 & 83.2 & 45.2 & 69.5 \\
\hline
\end{tabular}




\begin{tabular}{|l|l|l|l|l|l|}
\hline & 5 & 203.0 & 56.6 & 53.5 & 73.6 \\
\hline
\end{tabular}

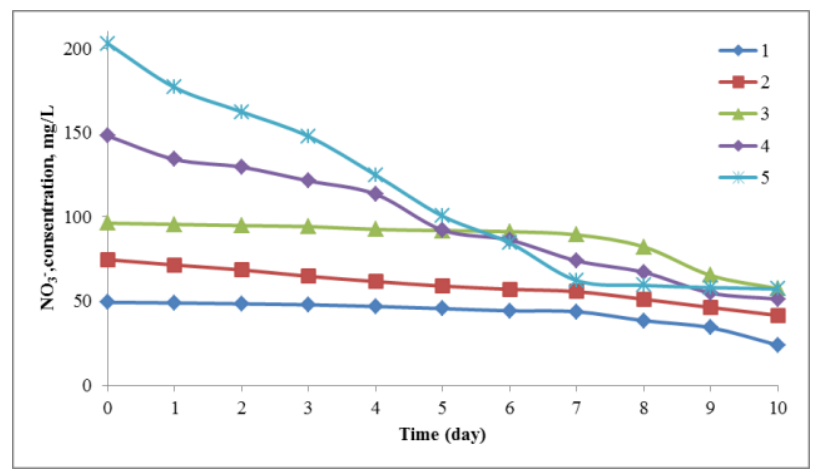

Fig. 1. Graph of a decrease in the concentration of nitrates in model solutions at a temperature of $20^{\circ} \mathrm{C}$

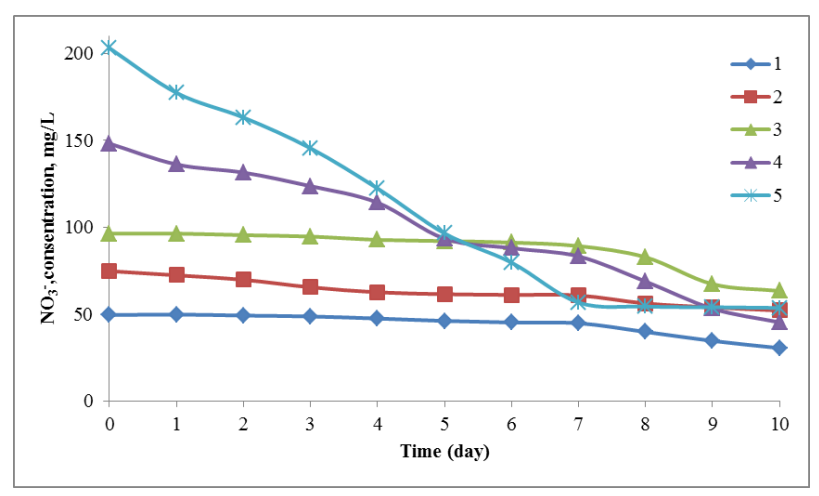

Puc. 2. Graph of a decrease in the concentration of nitrates in model solutions at a temperature of $3{ }^{\circ} \mathrm{C}$

Fig. 1 and Fig. 2 show a decrease in the concentration of nitrates in model solutions No. 1-5. For model solutions Nos. 1-3 at both temperatures, there was a gradual decrease in concentration over 7 days. The main decrease in the concentration of the pollutant was observed after the 7th day of the experiment. The concentration of nitrates in model solutions No. 4-5 decreased sharply from the first days of the experiment.

It can be seen that a decrease in the concentration of nitrates in model solutions No. 1-3 occurs more effectively at $20{ }^{\circ} \mathrm{C}(51.4 \%, 44.3 \%$ and $40.3 \%$ along with $38.5 \%, 30.4 \%$ and $34.3 \%$, respectively, for temperatures of $20{ }^{\circ} \mathrm{C}$ and $3{ }^{\circ} \mathrm{C}$ ), which is explained by more favourable temperature conditions. In model solutions No. 4-5, the decrease in concentration at temperatures of $20^{\circ} \mathrm{C}$ and $3{ }^{\circ} \mathrm{C}$ occurred with identical efficiency.

In addition, it should be noted that a decrease in the concentration of nitrates in model solutions with a higher concentration $(150 \mathrm{mg} / \mathrm{L}$ and $200 \mathrm{mg} / \mathrm{L})$ was more efficient than in model solutions with lower concentrations. This can be explained by the fact that the microalgae Chlorella kessleri, grown under nitrogen starvation conditions, enters the medium with a higher concentration of the component that is necessary for its vital activity. Having inorganic access to the nitrates, microalgae begin to absorb this component with greater intensity than in solutions with its low concentration.

\section{Recommendations and scope for future research}

The removal efficiency of nitrogen compounds is partly related to contaminants also present in the wastewater. Therefore, the effect of associated pollutants on the vital activities of microalgae and the process of removing nitrogen compounds must be considered. Consideration should also be given to microalgae absorption of various forms of nitrogen from aqueous solutions and other contaminants such as phosphorus.

Removal of nitrogen compounds is also possible with the combined action of microalgae and bacteria [11], as well as microalgae and plants [8]. Therefore, it is necessary to study bacteria and plants that can adapt to low temperatures and lead to an increase in the efficiency of removing pollutants.

In addition, the scalability of the process under consideration should be explored, as well as continuous operation and long-term efficiency. The effectiveness of large-scale use of microalgae strains in cold climates for wastewater treatment requires further research.

\section{Conclusions}

As a result of the experiment, it was shown that the frost-resistant microalgae strain Chlorella kessleri VKPM A1-11 ARW can be used to wastewater treatment from nitrogen compounds at low temperatures. It was noted that the efficiency of removing a pollutant from aqueous solutions at a temperature of $3{ }^{\circ} \mathrm{C}$ was identical to that of removing a pollutant at $20{ }^{\circ} \mathrm{C}$. It can be assumed that low temperatures do not significantly affect the life of algae.

\section{References}

1. J. Vymazal, Water (Switzerland) 2, 530-549 (2010)

2. Wastewater treatment in the Far North, Proceedings Of the international conference held in Canada, 72 (1972)

3. P.S. Lau, N.F.Y. Tam, Y.S. Wong, Enviromental Pollut 89, 59-66 (1995)

4. H. Jia, Q.Yuan, Cogent Environ. Sci. Cogent. 2, 1 (2016)

5. S.F.Mohsenpour et al, Sci. Total Environ. 752 (2021)

6. J.K. Pittman, A.P. Dean, O. Osundeko, Bioresour. Technol. Elsevier Ltd. 102, 17-25 (2011)

7. Гавриленко А.В. et al, Бюллетень науки и практики. 10, 42-46 (2016)

8. T. Mæhlum, P.D. Jenssen, W.S. Warner, Water Sci. Technol. 32, 95-101 (1995)

9. The climate of the Arctic. Air temperature. Available online: https://goarctic.ru/news/seo-temperaturaklimat-arktiki-temperatura-vozdukha/ (2020)

10. L. Ferro et al, Algal Res. Elsevier 35, 160-167 
(2018)

11.P.J. He et al. Bioresour. Technol. 146, 562-568 (2013) 